\title{
Effect of fat and sugar levels on acidity and total solids of shrikhand
}

\author{
MANVENDRA SINGH, RAMJI GUPTA, B.C. ANDHARE AND SHWETA SINGH
}

\begin{abstract}
Shrikhand as a semi-soft, sweetish sour, whole milk product prepared from lactic fermented curd, the curd is partially strained through a muslin cloth to remove the whey and thus produce a solid mass called chakka.This chakka is mixed with the required amount of sugar to yield Shrikhand. The dish is very popular in Gujarat, Maharashtra and Karnataka. The buffalo milk was standardized to three fat levels i.e. 4 per cent $\left(F_{1}\right), 5$ per cent $\left(F_{2}\right)$ and 6 per cent $\left(F_{3}\right)$. During the preparation of Shrikhand three levels of sugar i.e. 30 per cent $\left(\mathrm{S}_{1}\right), 40$ per cent $\left(\mathrm{S}_{2}\right), 50$ per cent $\left(\mathrm{S}_{3}\right)$ was added and then the Shrikhand was put in plastic cups and earthen pots. The impact of all treatment individually and their interaction was studied on total solids and yield of Shrikhand. The results of present investigation yield useful information of productive utility for higher fat in Shrikhand the treatments $\mathrm{F}_{3} \mathrm{xS}_{2}$ showed better result. The highest amount of fat was evaluated in $\mathrm{F}_{3} \mathrm{~S}_{2}$. Individually higher total solid content in Shrikhand was observed for the treatment 6 per cent fat and 40 per cent sugar level. The treatment $\mathrm{F}_{3} \mathrm{xS}_{2}$ result in maximum TS content of Shrikhand. On the basis of sensory and chemical examination of buffalo milk shrikhand, the maximum yield of shrikhand was noted in $F_{3} \times S_{3}$ sample followed by $F_{2} \times S_{2}$ and minimum yield of shrikhand was noted in $F_{1} \times S_{1}$ sample.
\end{abstract}

KEY WORDS : Fat, Sugar, Shrikhand, Sensory and chemical examination

How TO CITE THIS PAPER : Singh, Manvendra, Gupta, Ramji, Andhare, B.C. and Singh, Shweta (2015). Effect of fat and sugar levels on acidity and total solids of shrikhand. Res. J. Animal Hus. \& Dairy Sci., 6(2) : 125-129.

\section{MEMBERS OF RESEARCH FORUM}

Address for correspondence :

B.C. Andhare, Department of Animal Husbandry and Dairying, Institute of Agricultural Sciences, Banaras Hindu University, VARANASI (U.P.) INDIA

Email : andharebcshree@gmail.com

Associated Authors' :

Manvendra Singh, Department of Animal Husbandry and Dairying, Institute of Agricultural Sciences, Banaras Hindu University, VARANASI (U.P.) INDIA

Shweta Singh, Warner School of Food and Dairy Technology, ALLAHABAD (U.P.) INDIA

Ramji Gupta, Department of Animal Husbandry and Dairying, C.S.A. University of Agriculture and Technology, KANPUR (U.P.) INDIA 